\title{
Multi-period Quadratic Programming Model for Sewon-Bantul Facultative Ponds Optimization
}

\author{
Sunarsih*, Sutrisno \\ Department of Mathematics, Diponegoro University, 50275, Indonesia
}

\begin{tabular}{l} 
A R T I C L E I N F O \\
\hline Article history: \\
Received: 30 September, 2019 \\
Accepted: 12 December, 2019 \\
Online: 25 December, 2019 \\
\hline
\end{tabular}

Keywords:

Facultative pond

Quadratic programming

Wastewater treatment

\begin{abstract}
A B S T R A C T
Treatment plants have been developed in many countries to handle wastewater, therefore, many pieces of researches have been conducted in order to optimize the outcomes. In this article, a mathematical optimization model was developed using quadratic programming approach to optimize the pollutant degradation at the domestic wastewater facultative stabilization ponds. The data used in this research were obtained from Sewon, Bantul wastewater treatment plant (WWTP) located in Yogyakarta, Indonesia. The proposed mathematical optimization model was formulated by maximizing the total amount of domestic wastewater processed in four facultative ponds along with the efficiency index value of the biological oxygen demand (BOD) degradation. The corresponding quadratic programming problem was solved in LINGO 18.0 optimization tool by using the generalized reduced gradient algorithm. The result led to the optimal decision which is the value of the domestic wastewater processed in each facultative pond.
\end{abstract}

\section{Introduction}

The treatment of wastewater reduces its pollutant concentration through several processing levels. In Sewon, Bantul treatment plant, the process is conducted in three steps. It begins with the inception of the wastewater via inlet, following by filtering to remove its physical matters. It is further processed in the facultative pond to reduce pollutants, and processed in the maturation pond. In these steps, it is processed in order to reduce the pollutants such as bacteria, algae \& zooplankton, due to prolonged storage time [1]. In order to observe, evaluate, and optimize the pollutant degradation process in facultative ponds, researches were conducted, for example, using the following approaches: a quantitative method for coefficient analysing [2], linear programming for BOD degradation [3], an economically viable natural adsorbent materials approach for wastewater treatment [4], dynamic model for sewage treatment [5], quantitative analysis for nitrogen removal mechanism [6], maturation pond analysis [7], and an optimization model approach developed for energy saving and mitigation [8].

Some advance researches were conducted to develop new approaches for wastewater treatment model using specific methods such as statistical analysis approaches [9], distillation column model approach [10], phosphorus content analysis [11], physio-chemical \& micro-biological [12], oxygen electrode \& biological approach [13], organism \& organic matter analysis [14],

"Corresponding Author: Sunarsih, Email: narsih_pdil@yahoo.com quadratic programming approach [15], a multi-objective particle swarm optimization for conjunctive use of treated wastewater \& groundwater [16], fenton oxidation process optimization [17], data-driven in pumping station [18], WEST software approach for solid retention time optimization [19], integrated wastewater treatment for multiple input configurations, reuse, \& disposal options [20], electrochemical oxidation for saline wastewater treatment [21], and wastewater treatment optimization using moving bed biofilm reactor method [22]. Furthermore, some articles in the literature were published on the utilization of wastewater residual, such as, for brick making [23], recycling [24], sludge for biodiesel [25], microbial fuel cells for power generation [26], etc. Conversely, numerous implementations of its optimization were reported in many areas, for example in textile bio-refractory treatment [27], municipal and piggery [28], [29], eco-industrial park [30], cutting oil on twisted tapes [31], brewery [32], sugar beet industry processing [33].

Unfortunately, the existing approaches mentioned above were modelled as a single period processing which means that the model can handle for single time processing only. In order to handle the wastewater processing in multi-period way, a new model which including the processing time variable is needed. In this paper, a multi-period mathematical optimization model approach is developed to determine the optimal decision for BOD degradation in facultative ponds. This model is developed from our previous research with data collected from Sewon, Bantul facultative ponds located in Yogyakarta, Indonesia. 


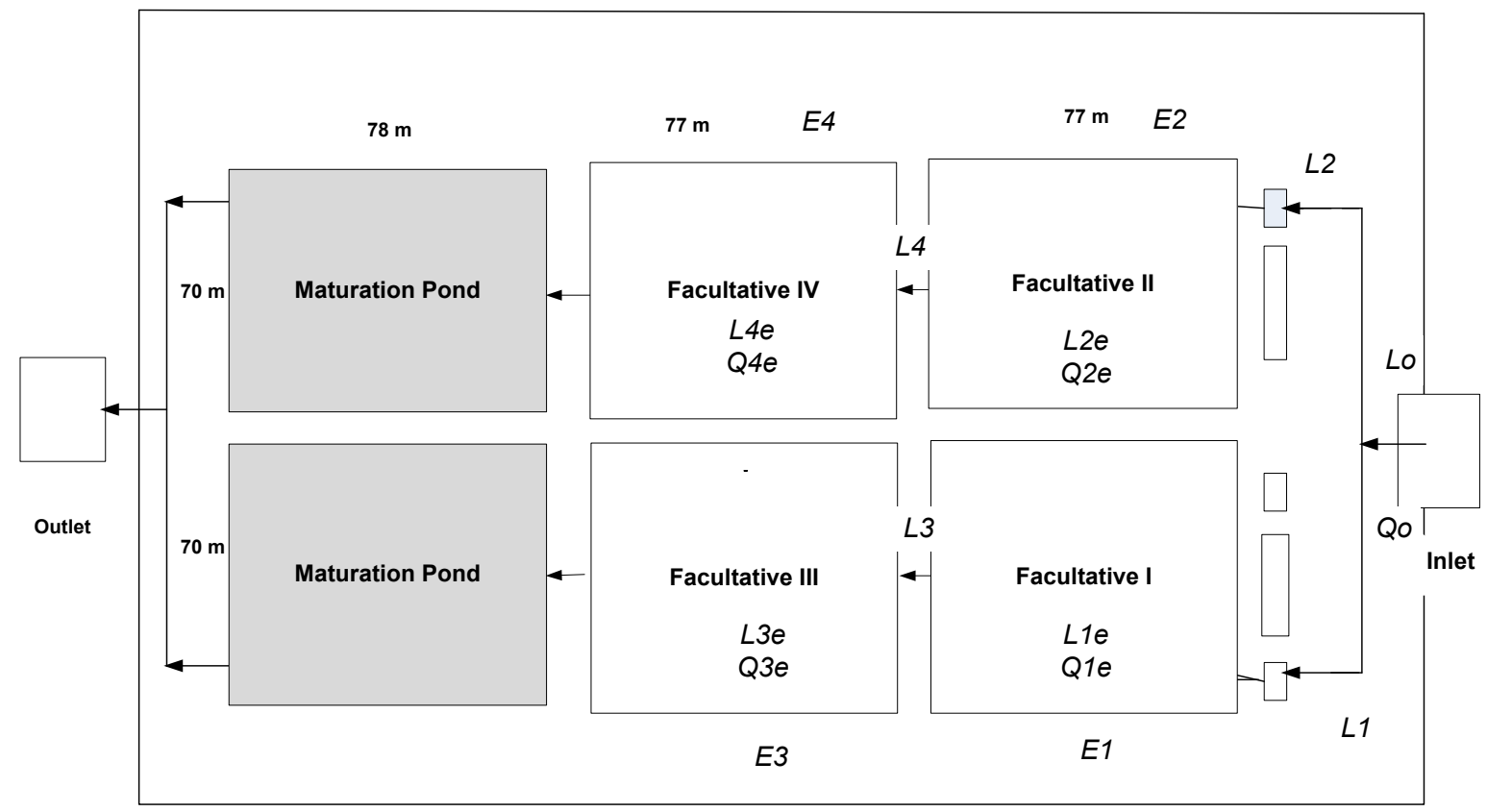

Figure 1: Sewon Bantul wastewater treatment plant [3]

\section{Material and Method}

\subsection{Assumptions and Notations}

The formulated mathematical model was considered under the following assumptions:

(1) Optimizing wastewater processing only on four facultative ponds, we do not including the processing in the maturation pond;

(2) The decision variable to be optimized is the BOD concentration parameter;

(3) The data used in the model and the calculation were observed in Sewon, Bantul facultative ponds;

(4) The data were taken from ponds I and II

(5) The pollutant degradation process was assumed to be uniform in all ponds;

(6) The quality standard value of the wastewater is taken from the government's policy, Yogyakarta Province [34];

(7) The formula to calculate the efficiency index value used in the model is based on our previous researches (see [3]);

(8) The review period of time is assumed to be a day.

Sewon, Bantul WWTP facility contains inlet and outlet valve, as well as four facultative and two maturation ponds (see Figure 1). The following notations are used in the mathematical model:

index:

$t \quad$ : review period of time (day)

decision variables:
$L_{p}^{e}(t)$
: Wastewater volume processed in pond $p$ at review time period $t(\mathrm{~kg} /$ period $)$

parameters:

$L_{0} \quad$ : Initial wastewater load volume in inlet (kg/day)

$Q_{0}(t) \quad:$ Wastewater inflow rate in the inlet at review time period $t\left(\mathrm{~m}^{3} /\right.$ period $)$

$Q_{p}^{e}(t) \quad:$ Wastewater inflow rate in facultative pond $p$ at review time period $t\left(\mathrm{~m}^{3} /\right.$ period $)$

$L_{p}(t) \quad:$ Wastewater load volume prior to pond $p$ at review time period $t(\mathrm{~kg} /$ period $)$

$C_{p}(t) \quad:$ Concentration of Biological Oxygen Demand at pond $p$ at review time period $t(\mathrm{mg} / \mathrm{L})$

$L(t) \quad: \quad$ Wastewater load for all ponds at review time period $t(\mathrm{~kg} /$ period $)$

$E_{p}(t) \quad:$ Efficiency value of the treatment at pond $p$ at review time period $t$ (in percentage)

$E_{\text {ref }}(t) \quad$ : reference value for the efficiency value of the treatment in the pond at review time period $t$

$B M \quad$ : Quality standards of wastewater decided by the local government (constant for all review time period)

\subsection{Mathematical Model}

We proposed the following mathematical model which was developed to maximize the load volume of the wastewater in all four facultative ponds and optimizing the efficiency index value of the BOD degradation by bringing it into a reference point decided by the decision maker. This was further formulated as a quadratic function of their difference, i.e.

$$
\max Z=\sum_{t=1}^{T} \sum_{p=1}^{P} L_{p}^{e}(t)-\sum_{t=1}^{T} \sum_{p=1}^{P}\left(E_{p}(t)-E_{r e f}(t)\right)^{2} .
$$

The following equalities/inequalities were formulated as the constraints to the model:

(1) The efficiency index value of the BOD degradation at each review period per facultative pond need to satisfy the wastewater quality standard $(B M)$ :

$$
E_{p}(t) \cdot C_{p}(t) \leq B M, \forall p \in\{1,2,3,4\} ;
$$


(2) The wastewater load volume in pond $p$ must not be exceeded:

$$
L_{p}^{e} \leq L_{p}, \forall p \in\{1,2,3,4\}
$$

(3) The wastewater load volume entering the facultative pond $p$ is the flow rate containing BOD:

$$
L_{p}^{e}(t)=\frac{\left(Q_{p}^{e}(t) \cdot C_{p}(t)\right)}{1000}, \forall p \in\{1,2,3,4\} ;
$$

(4) The efficiency index value for facultative pond $p$ at review period of time $t$ is

$$
E_{p}(t)=\frac{k \cdot S}{1+k \cdot S}, \forall p \in\{1,2,3,4\} ; ;
$$

where $k$ is the BOD degradation rate per day and $S$ is the storing time (in day) of the wastewater in the facultative pond.

The above mathematical model is rewritten as:

$$
\max Z=\sum_{t=1}^{T} \sum_{p=1}^{P} L_{p}^{e}(t)-\sum_{t=1}^{T} \sum_{p=1}^{P}\left(E_{p}(t)-E_{r e f}(t)\right)^{2}
$$

subject to

$$
\begin{gathered}
E_{p}(t) \frac{\left(1000 \cdot L_{p}(t)\right)}{Q_{p}^{e}(t)} \leq B M, \forall p=1,2,3,4 ; \\
L_{1}^{e}(t) \leq L_{1}(t) \\
L_{3}^{e}(t) \leq L_{1}(t)-L_{1}^{e}(t) \\
L_{2}^{e}(t) \leq L_{2}(t) \\
L_{4}^{e}(t) \leq L_{2}(t)-L_{2}^{e}(t) .
\end{gathered}
$$

\section{Results and Discussions}

The optimal decision is calculated using the following scenario with some parameter values collected in Sewon, Bantul WWTP as reported by previous published articles. The domestic wastewater load in ponds P1 and P2 is half of the inflow rate in the value of $L_{0}$ $=4.799,6 \mathrm{~kg} /$ day, with a BOD degradation coefficient of $1.1 \%$ [3], a quality standard of $50 \mathrm{mg} / \mathrm{L}$, and a wastewater inflow rate of $11238 \mathrm{~m}^{3} /$ day in each facultative pond for one year [3]. The reference value for the efficiency of the treatment at the pond is decided to be 0.25 for ponds P1 \& P2, and 0.5 for ponds P3 \& P4 at any review time period $t$. To solve the optimization problem(5), the LINGO programming tool was run in a daily used personal computer. The optimization results are shown in Figures 2 and 3. First, the optimal decision value for the wastewater load in pond P1 \& P2 is $112399 \mathrm{~kg}$ per day for each, and $1199.5 \mathrm{~kg}$ for P3 \& $\mathrm{P} 4$ as shown in Figure 2 with a review time period 5, which is processed in each pond by $1199.5 \mathrm{~m}^{3}$ where the storing time is 0.25 day at pond $\mathrm{P} 1,0.25$ day at pond $\mathrm{P} 2,0.57$ day at pond $\mathrm{P} 3$, and 0.57 day at pond $\mathrm{P} 4$.

In order to simulate the problem in difference scenarios, the optimal decision was calculated with scenarios following the value of the wastewater load in facultative pond $p$ at review time period $t\left(\mathrm{~m}^{3} /\right.$ period $)$ in Figure 2. The optimal decision, i.e. the wastewater volume to be processed in pond $p$ at each review time $t(\mathrm{~kg} / \mathrm{period})$ is shown in Figure 3. The optimal storing time is the same for all each review time i.e. 0.25 day at pond P2 \& P3, and 0.57 day at pond P3 \& P4.

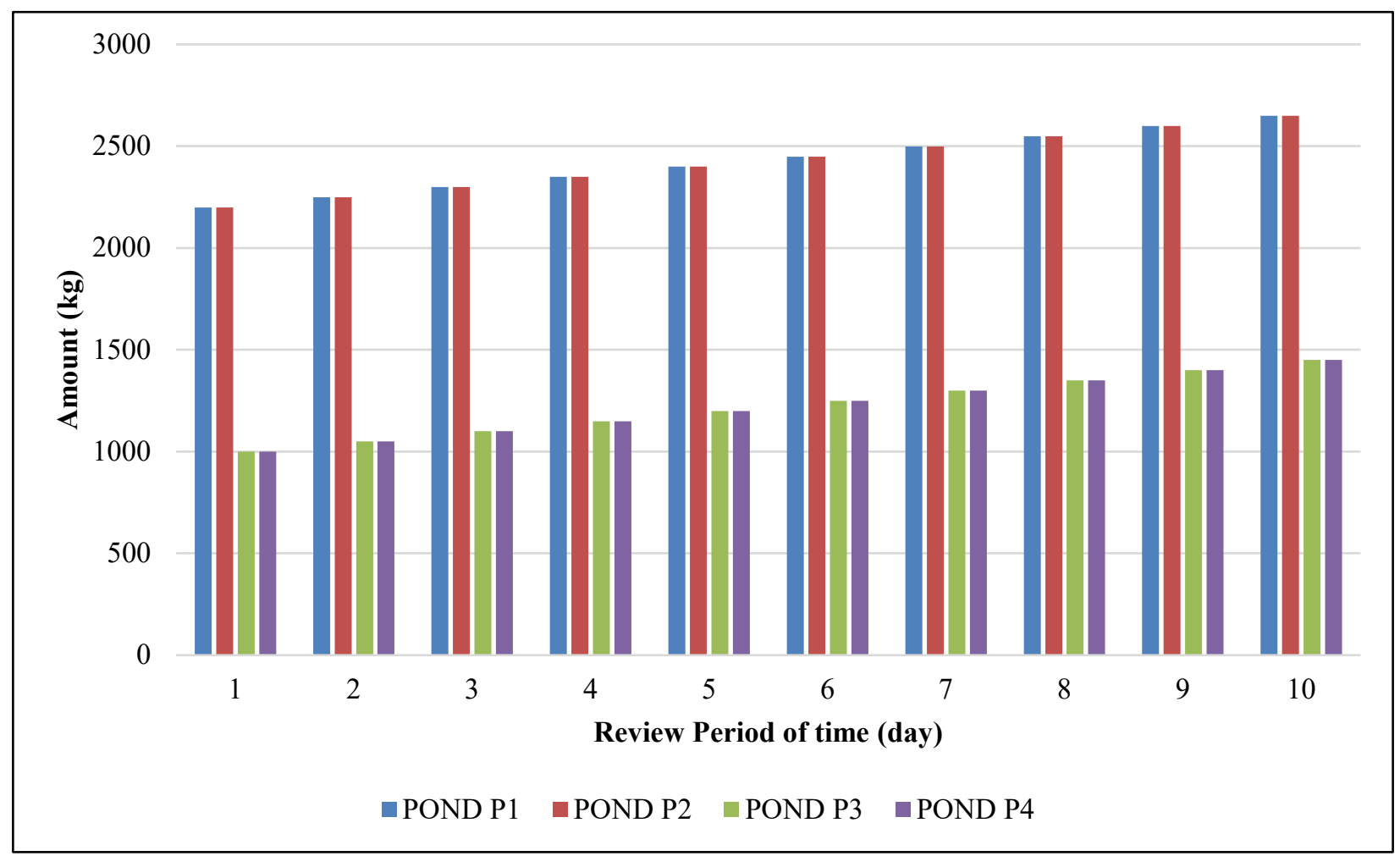

Figure 2: Wastewater load in facultative pond $p$ at review time period $t(\mathrm{~kg} /$ period $)$ 


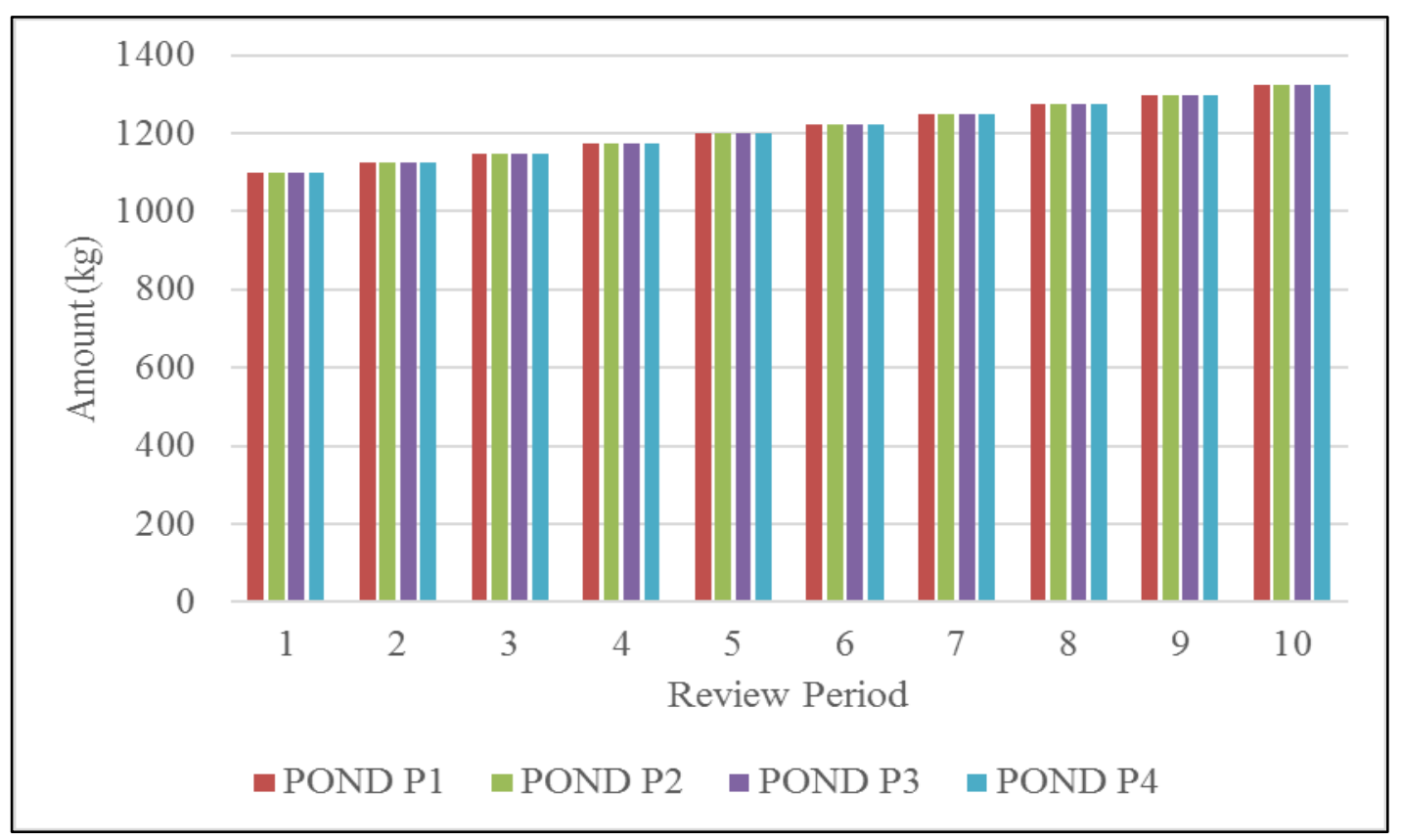

Figure 3: Wastewater volume processed in pond $p$ at review time period $t(\mathrm{~kg} / \mathrm{period})$

\section{Concluding Remarks}

An optimization mathematical model in a quadratic programming was proposed in this paper which is used to calculate the optimal amount of domestic wastewater to be processed in facultative stabilization ponds. The model was solved using data collected at Sewon, Bantul WWTP, and from the computational experiment, the facultative pond was derived with the storing time at each pond.

The authors declare no conflict of interest.

\section{Acknowledgment}

Authors thank to LPPM Universitas Diponegoro for funding support under RPP Research Grant Contract No. 32946/UN7.P4.3/PP/2019.

\section{References}

[1] S. Sunarsih, P. Purwanto, and W. S. Budi, "Mathematical modeling regime steady state for domestic Wastewater Treatment facultative stabilization ponds," J. Urban Environ. Eng., vol. 7, no. 2, pp. 293-301, 2013.

[2] B. sheng Huang et al., "Quantitative study of degradation coefficient of pollutant against the flow velocity," J. Hydrodyn., vol. 29, no. 1, pp. 118$123,2017$.

[3] Sunarsih, Widowati, Kartono, and Sutrisno, "Mathematical Analysis for the Optimization of Wastewater Treatment Systems in Facultative Pond Indicator Organic Matter," E3S Web Conf., vol. 31, no. 05008, pp. 1-3, 2018.

[4] A. Gopakumar, R. Narayan, S. A. Nagath, N. P, R. Mohammed. S, and S. Chandran .S, "Waste Water Treatment Using Economically Viable Natural Adsorbent Materials," Mater. Today Proc., vol. 5, no. 9, pp. 17699-17703, 2018.

[5] D. Recio-Garrido, Y. Kleiner, A. Colombo, and B. Tartakovsky, "Dynamic model of a municipal wastewater stabilization pond in the arctic," Water Res. vol. 144, pp. 444-453, 2018.

[6] A. W. Mayo and M. Abbas, "Removal mechanisms of nitrogen in waste stabilization ponds," Phys. Chem. Earth, vol. 72-75, pp. 77-82, 2014.

[7] F. Cortés Martínez, A. Treviño Cansino, A. Sáenz López, J. L. González Barrios, and F. J. De La Cruz Acosta, "Mathematical modeling and optimization in the design of a maturation pond," J. Appl. Res. Technol., vol. 14, no. 2, pp. 93-100, 2016.

[8] S. Borzooei et al., "Optimization of the wastewater treatment plant: From energy saving to environmental impact mitigation," Sci. Total Environ., vol. 691, pp. 1182-1189, 2019

[9] F. Halters, E. Zondervan, and A. De Haan, "Integrated optimization of a waste water treatment plant using statistical analysis," J. Hazard. Mater., vol. 179, no. 1-3, pp. 480-487, 2010.

[10] F. Ferella, "Journal of Environmental Chemical Engineering Optimization of a plant for treatment of industrial waste solutions: Experimental and process analysis," J. Environ. Chem. Eng., vol. 6, no. 1, pp. 377-385, 2018.

[11] M. D. Sells, N. Brown, and A. N. Shilton, "Determining variables that influence the phosphorus content of waste stabilization pond algae," Water Res., vol. 132, pp. 301-308, 2018.

[12] L. T. Ho, A. Alvarado, J. Larriva, C. Pompeu, and P. Goethals, "An integrated mechanistic modeling of a facultative pond: Parameter estimation and uncertainty analysis," Water Res., vol. 151, pp. 170-182, 2019.

[13] M. Novak and P. Horvat, "Mathematical modelling and optimisation of a waste water treatment plant by combined oxygen electrode and biological waste water treatment model," vol. 36, pp. 3813-3825, 2012.

[14] F. C. Martínez, A. T. Cansino, M. Aracelia, A. García, V. Kalashnikov, and R. L. Rojas, "Mathematical Analysis for the Optimization of a Design in a Facultative Pond : Indicator Organism and Organic Matter," Math. Probl. Eng., vol. 2014, no. 1, pp. 1-12, 2014.

[15] Sunarsih, D. P. Sasongko, and Sutrisno, "Process Improvement on Domestic Wastewater Treatment Stabilization Ponds by Using Mathematical Optimization Approach," Mat. MJIAM, vol. 35, no. 2, pp. 171-176, 2019.

[16] M. Youse, M. Ebrahim, J. Soltani, and A. Roozbahani, "Multi-objective particle swarm optimization model for conjunctive use of treated wastewater and groundwater," Agric. Water Manag. J., vol. 208, pp. 224-231, 2018.

[17] M. Zhang, H. Dong, L. Zhao, D. Wang, and D. Meng, "A review on Fenton process for organic wastewater treatment based on optimization perspective," Sci. Total Environ., vol. 670, pp. 110-121, 2019.

[18] J. Filipe, R. J. Bessa, M. Reis, R. Alves, and P. Póvoa, "Data-driven predictive energy optimization in a wastewater pumping station," Appl. Energy, vol. 252, no. February, p. 113423, 2019.

[19] R. Muoio et al., "Optimization of a large industrial wastewater treatment plant using a modeling approach : A case study," J. Environ. Manage., vol. 249, no. May, p. 109436, 2019.

[20] M. S. Ang, J. Duyag, K. C. Tee, and C. L. Sy, "A multi-period and multicriterion optimization model integrating multiple input configurations, reuse, and disposal options for a wastewater treatment facility," J. Clean. Prod., vol. 231, pp. 1437-1449, 2019.

[21] M. Darvishmotevalli and A. Zarei, "Optimization of saline wastewater treatment using electrochemical oxidation process: Prediction by RSM method," MethodsX, vol. 6, pp. 1101-1113, 2019. 
[22] R. K. Sonwani, G. Swain, B. S. Giri, and R. S. Singh, "A novel comparative study of modified carriers in moving bed biofilm reactor for the treatment of wastewater : Process optimization and kinetic study," Bioresour. Technol. J., vol. 281, pp. 335-342, 2019.

[23] L. P. Rodrigues, J. Nilson, and F. Holanda, "Recycling of Water Treatment Plant Waste for Production of Soil- Cement Bricks," Procedia Mater. Sci., vol. 8, pp. 197-202, 2015.

[24] S. Raghuvanshi, V. Bhakar, C. Sowmya, and K. S. Sangwan, "Waste water treatment plant life cycle assessment : treatment process to reuse of water," Procedia CIRP, vol. 61, pp. 761-766, 2017.

[25] S. Mohseni and M. S. Pishvaee, "Data-driven robust optimization for wastewater sludge-to-biodiesel supply chain design," Comput. Ind. Eng., vol. in press, 2019.

[26] H. Mehravanfar, M. A. Mahdavi, and R. Gheshlaghi, "Economic optimization of stacked microbial fuel cells to maximize power generation and treatment of wastewater with minimal operating costs," Int. J. Hydrogen Energy, vol. 44, no. 36, pp. 20355-20367, 2019.

[27] A. Stéphane, K. Edmond, A. Emmanuella, K. Adouby, and P. Drogui, "Insitu generation of effective coagulant to treat textile bio-refractory wastewater: Optimization through response surface methodology," $J$. Environ. Chem. Eng., vol. 6, no. 4, pp. 5587-5594, 2018.

[28] L. D. S. Leite, M. Teresa, and L. A. Daniel, "Microalgae cultivation for municipal and piggery wastewater treatment in Brazil," J. Water Process Eng., vol. 31, pp. 1-7, 2019.

[29] J. Lu, X. Wang, H. Liu, H. Yu, and W. Li, "Optimizing operation of municipal wastewater treatment plants in China: The remaining barriers and future implications," Environ. Int., vol. 129, no. March, pp. 273-278, 2019.

[30] E. O. Dwyer, K. Chen, H. Wang, A. Wang, N. Shah, and M. Guo, "Optimisation of wastewater treatment strategies in eco-industrial parks: Technology, location and transport," Chem. Eng. J., vol. 381, no. March 2019, p. 122643, 2020.

[31] S. Popovi and M. Karad, "Optimization of ultra filtration of cutting oil wastewater enhanced by application of twisted tapes: Response surface methodology approach,” J. Clean. Prod. J., vol. 231, pp. 320-330, 2019.

[32] R. Singh, P. Bhunia, and R. R. Dash, "Optimization of organics removal and understanding the impact of HRT on vermifiltration of brewery wastewater," Sci. Total Environ., vol. 651, pp. 1283-1293, 2019.

[33] S. Sharma and H. Simsek, "Sugar beet industry process wastewater treatment using electrochemical methods and optimization of parameters using response surface methodology," Chemosphere, vol. 238, p. 124669, 2020.

[34] Gubernur DI Yogyakarta (Governor of Special Region Yogyakarta), Surat Keputusan Gubernur Kepala Daerah Istimewa Yogyakarta (Decree of Special Region Yogyakarta Governor) No. 214/KPTS/1991. 1991. 